\title{
Impacts of Climate Change on Hydroelectric Power Generation - A Case Study Focused in the Paranapanema Basin, Brazil
}

\author{
Rafael de Oliveira Tiezzi ${ }^{1}$, Nathália Duarte Braz Vieira ${ }^{2}$, André Felipe Simões ${ }^{3}$, Homero Fonseca Filho ${ }^{4}$, \\ Ednílson Viana ${ }^{4}$, Dominique Mouette ${ }^{4} \&$ Mariana Soares Domingues ${ }^{4}$ \\ ${ }^{1}$ Assistant Professor at Federal University of Alfenas - UNIFAL, Brazil \\ ${ }^{2} \mathrm{PhD}$ student in Energy Planning Systems of State University of Campinas - UNICAMP, Brazil \\ ${ }^{3}$ Associate Professor at School of Arts, Sciences and Humanities of University of São Paulo - EACH/USP, Brazil \\ ${ }^{4}$ Assistant Professor at School of Arts, Sciences and Humanities of University of São Paulo - EACH/USP, Brazil \\ Correspondence: Nathália Vieira, Mechanical Engineering Department, University of Campinas, Campinas, SP, \\ Brazil. Tel: 55-019-98444-4595. E-mail: nathaliadbv@unifei.edu.br
}

Received: September 14, 2017

doi:10.5539/jsd.v11n $1 \mathrm{p} 140$
Accepted: January 10, $2018 \quad$ Online Published: January 30, 2018

URL: https://doi.org/10.5539/jsd.v11n1p140

\begin{abstract}
Climate change is taking special attention among the economic agents, especially due to the uncertainties and risks associated with it. In countries with a significant share of renewables in their energy matrix, this phenomenon implies on challenges for the energy planning in future scenarios. In this context, this study establishes a correlation between energy security and climate change by understanding the ability to generate hydroelectric power in large-scale hydroelectric (HEP) and small hydroelectric plants (SHP), in the Alto Paranapanema Basin (São Paulo, Brazil), a region with rainfall anomalies and water flow changes due to climate change. This region was chosen based on its future scenarios on climate change, especially those of rainfall anomalies and change in water flow, using the Soil Moisture Accounting Procedure (SMAP) mathematical model. The water flow was simulated in the HidroLab model, resulting in the generation of hydroelectric power. The results indicated a loss of generation capacity, that can be attributed to negative anomalies of rainfall and its direct influence on river flow, which is a fundamental factor in hydropower generation. Thus, this study draws attention to the importance of considering climate vulnerability in energy planning now and in the future.
\end{abstract}

Keywords: climate change, impacts of climate variability, hydroelectric power generation in Brazil, rainfall variation, energy security

\section{Introduction}

Global climate variability, especially climate change and global warming, has become a major concern for governments, NGOs, companies, and society in general as its impacts on economies, population, food production, and the environment. The Intergovernmental Panel on Climate Change (IPCC) was categorical in stating that the observed global warming of the past 50 years is due to the accumulation of greenhouse gases generated by human activities. These greenhouse gases, especially carbon dioxide and methane, have the highest atmospheric concentrations in the last 650000 years of the history of the planet.

The Fifth IPCC Report projected that by 2100 the mean global temperature could rise on average from $2^{\circ} \mathrm{C}$ to more than $4^{\circ} \mathrm{C}$ (IPCC, 2014). Consequently, the high latitudes and the equatorial Pacific are likely to experience an increase in annual mean precipitation. In many mid-latitude and subtropical dry regions, mean precipitation will likely decrease while in mid-latitude wet regions, mean precipitation will likely increase. Extreme precipitation events over most mid-latitude land masses and over wet tropical regions will very likely become more intense and more frequent as global mean surface temperature increases. Globally, in all scenarios studied by IPCC, it is likely that the area encompassed by monsoon systems will increase and monsoon precipitation is likely to intensify and El Niño-Southern Oscillation (ENSO) related precipitation variability on regional scales will likely intensify (IPCC, 2014).

The energy use is dependent on natural resources, and the availability and reliability of renewable sources are function of climate conditions, which can vary according to global climate changes (Lucena, Szklo, Schaeffer \& Dutra, 2010). Climatic variability and climate change effects impacts on water resources use and associated 
environmental conservation efforts (Schaeffer et al., 2012). In the history of civilization, it is common to correlate the migration of people and water availability, as well as combinations of changes in climate, soil, water and other physical factors. A well-documented example is the correlation between the frequent droughts that occur in the Brazilian Northeast region and its historically tenuous social and economic development and the large migration of the affected population to other parts of the country, especially to the Southeastern region of Brazil (Tucci, 2002).

Brazilian electricity matrix is extremely dependent on water resources. According to the National Energy Balance (BEN, in Portuguese), hydroelectric power plants accounted for $64.0 \%$ of domestic electric supply in 2015, against of $74.0 \%$ in 2010, indicating a reduction in recent years (Empresa de Pesquisa Energética [EPE], 2011; 2016). In fact, Brazil faced a water scarcity period in 2013 that resulted in a serious problem for energy security in country. On the one hand, the drought reduced the levels of the reservoirs, while energy demand increase stimulated especially by Provisional Measure ${ }^{\circ} 579$ (BRASIL, 2013). Consequently, it was necessary to activate almost total thermal power plants, worsening emissions in country and its contribution to climate change.

According to the National Conjuncture of Brazilian Water Resources (ANA, 2015), since 2012 there is a gradual and intense reduction in the rainfall indices in some regions of the country (whose causes are not understandable given the short period studied), affecting significantly the supply of water in the Brazilian semi-arid, and in more populated areas and of greater water demand, such as São Paulo and Rio de Janeiro.

In fact, Brazilian energy and water planning do not evaluate the possible impacts of climate change on natural resources. The National Policy for Water Resources (PNRH in Portuguese) do not considers climate vulnerability explicitly in its guidelines, but states that Brazilian water resources must be managed "[...] to ensure the current and future generations the necessary availability of water, in quality standards appropriate to their uses". The politics also aims the prevention and protection against critical hydrological events, natural or resulted from inappropriate use of natural resources (BRASIL, 1997). Currently, Brazilian energy planning focuses especially on mitigating greenhouse gas emissions from the matrix by expanding alternative sources, replacing fuels and energy efficiency actions. However, risk management is still not considered as a fundamental factor in public energy policies.

In this context, a systematic view of the hydro climatic processes at global and mid-scale levels, which are highly important, it also is necessary to understand the impacts from this variability so that mitigating or preventative measures can be planned.

Tucci \& Clarke (1998) and Collischonn, Tucci \& Clarke (2001) showed that large-sized basins in South America, such as those associated to the rivers Paraguay and Parana, and in Africa showed long periods with differing water flow tendencies. After the 1970s, an increase was recorded in rainfall and river flow in South America while, in Africa, during the same period, there was a substantial reduction in the same parameters, raising questions regarding the causes of these phenomena. Tucci \& Clarke (1998) and Collischonn et al. (2001) suggested that these long-term tendencies might have been influenced by anthropic conditions such as soil use or warming due to the anthropogenic intensification of the greenhouse effect, but science has not yet managed to identify the causes due to the short periods inherent to the information. In this context, is necessary to analyze the correlation between the climate change impact in each sector of water resources and its uses to the impact on the social and economic development and the environmental preservation of each region.

In the last years, several studies aim to evaluate the issue of climate vulnerability and its effects on hydroelectric generation. Schaeffer, Lucena \& Szklo (2008) estimated losses from $1.0 \%$ to $2.2 \%$ in electricity production of hydraulic origin for the case of Brazil as a whole. The projections by Lucena et al. (2009) indicated a mean potential loss in some electricity generation in the basins of the rivers Paraná, Grande, Paranaíba, Paranapanema, Parnaíba, São Francisco and Tocantins of $1.58 \%$ for A2 scenario and $3.15 \%$ for the B2 scenario (Note 1). According to Cleto (2008), electricity production in Portugal will decrease from $5 \%$ to $6 \%$ loss in the fall and spring, a $15 \%$ loss in the winter and a slight $1-2 \%$ increase in the summer.

In such context, the present study objective is to focus on an area these previous studies did not focus on, which is the correlation of potential impact of the climate alterations on water resources and subsequently on hydroelectric power generation, a theme little explored in Brazil and in many other countries (Bazilian, Hobbs, Blyth, MacGill \& Howells, 2011; Schaeffer et al. 2012).

In summary, the main objective of the present study was to analyze the climatic variability degree, which drive changes in seasonality and quantity of rainfall, and can alter the physiological behavior of a body of water in its hydrographic basin. This change also alters the water availability, which impacts electricity generation by 
hydroelectric plants (HEP) or from small hydroelectric plants (SHEP). A secondary objective of the present study was to assess whether there is proportionality in the loss factors between rainfall, flow and electricity generation. The Brazilian region chosen was the Alto Paranapanema Basin located in Sao Paulo state. This region houses the largest industrial park and the greatest economic production of Brazil, where closer $30 \%$ of the Brazilian GNP is produced and whose historically high electricity consumption has an intrinsic relationship with its notable economic power (EPE, 2011).

\section{Method}

A well-known and proven methodology developed by Hamada, Gonçalves, Marengo \& Ghini (2008) was chosen to be used in the present study. In this methodology, the scenarios of changes in the rainfall seasonality and volume were used as database for numerical modeling (see Table 1, as follow). From these scenarios, the SMAP (Soil Moisture Accounting Procedure) hydrological model was used to predict water performance in the basin and these data were then imported into the HidroLab model, simulating hydraulic electricity operation and generation in a HEP and a SHEP.

Table 1 . Mean daily rainfall anomalies ( $\mathrm{mm} /$ day)

\begin{tabular}{lcccccc}
\hline \multirow{2}{*}{ Month } & \multicolumn{2}{c}{2020} & \multicolumn{2}{c}{2050} & \multicolumn{2}{c}{2080} \\
\cline { 2 - 7 } & $\mathrm{A} 2$ & $\mathrm{~B} 2$ & $\mathrm{~A} 2$ & $\mathrm{~B} 2$ & $\mathrm{~A} 2$ & $\mathrm{~B} 2$ \\
\hline January & -1.34 & -1.16 & -1.26 & -1.00 & -1.09 & -0.97 \\
February & -0.16 & -0.04 & -0.22 & 0.10 & -0.13 & 0.04 \\
March & -0.04 & -0.34 & -0.07 & 0.02 & -0.28 & -0.24 \\
April & -0.10 & -0.01 & -0.13 & -0.05 & -0.02 & -0.08 \\
May & -0.18 & -0.11 & -0.21 & -0.18 & -0.26 & -0.18 \\
June & 0.10 & 0.14 & 0.19 & 0.13 & 0.15 & 0.13 \\
July & 0.09 & 0.08 & 0.11 & 0.13 & 0.09 & 0.09 \\
August & 0.12 & 0.13 & 0.15 & 0.14 & 0.08 & 0.10 \\
September & -0.01 & -0.10 & -0.13 & -0.24 & -0.27 & -0.16 \\
October & 0.18 & 0.12 & 0.08 & -0.18 & -0.06 & 0.13 \\
November & 0.31 & 0.13 & 0.13 & 0.48 & 0.07 & 0.44 \\
December & -0.61 & -0.61 & -0.77 & -0.55 & -0.49 & -0.38 \\
\hline Source: Adapted
\end{tabular}

Source: Adapted from Hamada et al. (2008).

Hamada et al. (2008) used the A2 and B2 scenarios described by the Intergovernmental Panel on Climate Change (IPCC, 2007), and are part of the four scenarios (A1, A2, B1 and B2) created by the IPCC for studies on climate change. Each scenario is distinguished from the other by different perspectives regarding changes in energy uses, sustainability actions, economic scenarios and other social, economic and environmental indicators.

The climate scenarios used in the simulations were scenarios A2 and B2 of IPCC (or, more precisely, the A2 and B2 scenario families). Scenario A2 refers to the most drastic scenario regarding climatic changes, that is, with the most significant impacts of temperature increase and climatic variation. Scenario B2 refers to a less drastic scenario of climate changes, characterized by more gentle temperature increases and climatic variations.

\subsection{Models Used and Calibration Required}

The SMAP hydrological model is a rainfall-flow transformation model where mean monthly rainfall values for the hydrographic basins studied and values obtained of mean monthly flow of the body of water in question are used as entry data points. The SMAP model is a flow simulation model and its usage require a careful calibration process to produce results with the greatest possible significance (Lopes, Braga \& Conejo, 1982; Lopes 1999). The SMAP model is calibrated using past rainfall and flow data in the basin under study where the model creates an equation that explains the basin performance, as recommended and used by Muñoz \& Sailor (1998).

The HidroLab program was also utilized in this study due to the system's characteristic of managing a set of optimization, prediction and simulation models which help to solve problems of planning the operation decisions 
of the systems on medium and long-term horizons, and the programming of operations on short-term horizons (Cicogna, 1999; 2003; Cicogna \& Soares Filho, 2005). The HidroLab has a set of advanced characteristics, it is supported by a database of 104 registered plants and it manages a set of optimization, prediction and simulation tools in addition to a databank. The tools of the HidroLab used in this study were:

- HidroData, it manages the recorded data from 104 Brazilian hydroelectric plants (Cicogna \& Soares Filho, 2005) all of which are dispatched in the National Interlinked System (SIN) by the National Electricity System Operator (ONS). It contains the databank with the information necessary to execute the required simulations;

- Hidromax, it was developed to optimize the energetic operation. It is an optimization model of individualized plants based on flow of capacitated networks with a non-linear objective;

- The HidroSim model LT (long-term), it is a simulation model of hydroelectric plant operation. The description of the simulation horizon is the same adopted for the HydraMax optimization model, providing data and result exchange among the optimization and simulation models.

After concluding the calibration step of the Hidrolab model, the parameter values obtained were inserted to be executed to obtain the flow series. The rainfall values from the rainfall collection sites, dated between 1961 and 1990 (considered as the current scenario) were inserted in the model and a flow series was generated for the period. The series altered by the climatic changes followed the same sequence, but before being applied to the model, the anomalies presented in Table 1 were added to the rainfall values from 1961 to 1990 for both the scenarios (A2 and B2) and the periods (1991-2020, 2021-2050 and 2051-2080).

The current and future flow values obtained in the Hidrolab model were used to simulate electricity generation. For the application of the HidroSim and HidroMax tools an HEP operation policy must be utilized. HEP operation policies are used in the operation of a reservoir plant, which determines how much water to save in the reservoir or if maximizing electricity production is the priority. The HEP policy chosen for the HidroSim and HidroMax tools was twofold, first was to maximize the firm electricity production for each year while maximizing hydroelectric power generation in order to cut costs with thermal power complementation, as this is more expensive than generating hydro energy. These policies were not adopted in the case of the SHEP because the electricity energy generation system in SHEP, run of the river, does not allow policies. In the case of SHEPs, since the ability to store water in reservoirs is not available, all the water that arrives at the plant has two main uses: the water is turbinated to generate electricity or flows out. Applying the Hidrolab model to the SHEP is restricted to simulating the maximum electric power production by modeled flow since the simulation allows that the flow that exceeds energy production of $30 \mathrm{MW}$ flows out.

\subsection{The Study Area}

The study area is in the Great Hydrographic Basin of the Paraná River, more precisely in the Alto Paranapanema Basin (see the following Figure 1), also called the Water Resources Management Unit - UGRHI 14. The location was chosen because its physical characteristics are very close to an environment in its natural state, that is, the river source has little anthropic alteration and significant changes are not found in the location in the natural water volume of the rivers. 


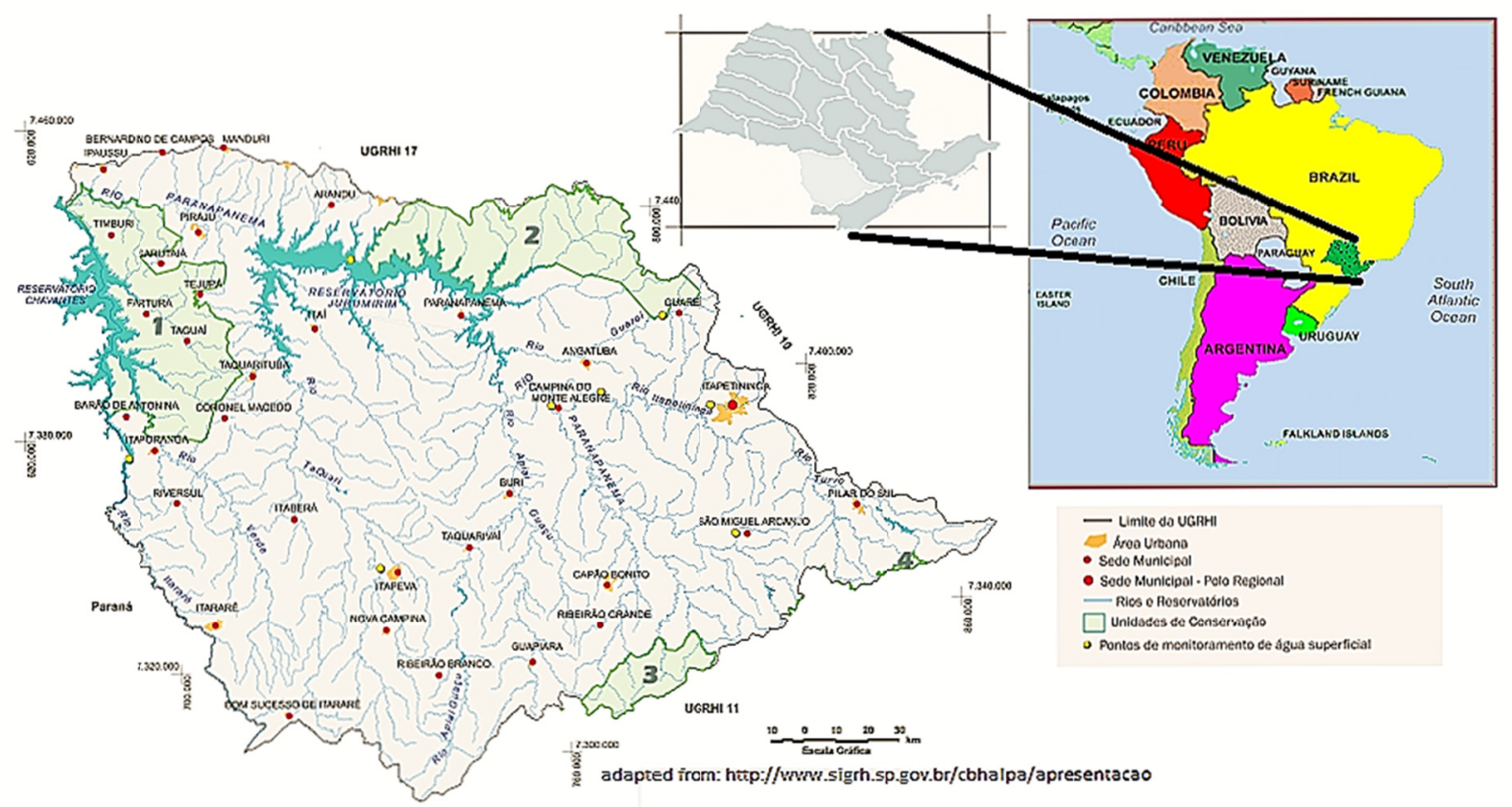

Figure 1. Localization of the State of São Paulo, in Brazil, and the Alto Paranapanema Basin, in the State of São Paulo. Source: Adapted from SIGRH, 2017.

There are three electricity power plants in operation in this basin: the Jurumirim HEP, the São José SHEP and the Santa Maria SHEP.

The Jurimirim HEP, also known as the Arnaldo Avellanal Laydner Plant, is located in the municipality of Cerqueira César and belongs to the Duke Energy Company. The plant has a $4490 \mathrm{~km}^{2}$ reservoir and $97.8 \mathrm{MW}$ installed capacity. The São José and Santa Maria SHEPs are upstream from the Jurumirim HEP and generate electricity for the consumption by a private company. These plants are located in private property and the access to the real data of the plants was not available, preventing their registration in the HidroLab. The data of the Armando Salles de Oliveira HEP, also known as the Limoeiro HEP, was used instead, as the objective of the present study was to analyze the water flow of the river for energy planning purposes and its impacts of the climate variation on the generation of hydraulic electricity generation in SHEPs and HEPs equipped with a reservoir similar to the parameters of the São José and Santa Maria SHEPs.

The Limoeira HEP and its data represent the best alternative due to the physical similarities. Based on the National Electricity Agency (ANEEL in Portuguese) resolution $\mathrm{n}^{\circ}$ 394, of December 4th, 1998, SHEPs must have power capacity between 1 and $30 \mathrm{MW}$ and up to $3.0 \mathrm{~km}^{2}$ flooded area, delimited by the full flow quota. The Limoeira HEP, has $32 \mathrm{MW}$ installed power and a $2.93 \mathrm{~km}^{2}$ full flow reservoir. This approximates the physical characteristics of the data in question to the physical characteristics of a SHEP and a maximum generation value of $30 \mathrm{MW}$ was established for the Hidrolab model simulation.

\section{Results}

The following Table 2 show the results of the simulation of power generation for the Jurumirim SHEP in the context of the A2 and B2 optimized scenarios, respectively, to minimize expenses with thermal complementation. The results were generated by comparing the generation in the different periods under study to show losses and gains for the different periods analyzed. 
Table 2. Electricity generation for the A2 and B2 scenarios in the Jurimirim Small Hydroelectric Plant

\begin{tabular}{ccccc}
\hline Scenario & $\begin{array}{c}\text { Time horizon in years } \\
\text { analyzed }\end{array}$ & $\begin{array}{c}\text { MW (average; } \\
\text { approximate } \\
\text { value) }\end{array}$ & $\begin{array}{c}\text { Minimum value reached in } \\
\text { the simulation - MW } \\
\text { (approximate value) }\end{array}$ & $\begin{array}{c}\text { Maximum value reached } \\
\text { in the simulation - MW } \\
\text { (approximate value) }\end{array}$ \\
\hline A2 & $1991-2020$ & 57.5 & 29 & 90 \\
B2 & $1991-2020$ & 59 & 34 & 90 \\
A2 & $2021-2050$ & 54.5 & 28 & 84 \\
B2 & $2021-2050$ & 56.5 & 33 & 84 \\
A2 & $2051-2080$ & 52.5 & 27 & 83 \\
B2 & $2051-2080$ & 60.5 & 34 & 83 \\
\hline
\end{tabular}

In the case of the 3 SHEPs analyzed, a significant discrepancy was found in the months of November compared to the other months. This discrepancy best be understood by analyzing Table 1 which shows the greatest anomaly values. In this context, the subsequent issue is why this discrepancy did not occur in the Jurumirim HEP simulation since rainfall was of the same quantity and all the hydroelectric plants are located in the same geographical region. The explanation for this discrepancy is that the Jurumirim HEP has a reservoir which allows it to store water and better manage and control the water flow to the plant turbines.

In this context, it is important to observe that for the Jurumirim plant, December and January presented a quantity of periods with greater power generation than in the other months. In fact, Table 1 analysis shows that these months have negative rainfall anomalies. Since the plant has a reservoir to store water, the electricity generation gains in December and January are associated to the high rainfall indices in the previous months, mainly due to the significant rainfall increases in November. This explains the discrepancy between the quantity of years with electricity generation gain of the Jurumirim and the SHEPs whose do not have a reservoir.

It seems clear that, in the case of Jurumirim, the excess of water in November served to increase the generation gains in the following months, minimizing the impact of the change in rainfall seasonality on electricity generation. Unlike HEPs, SHEPs, which do not have water reservoirs, experienced the largest electricity generation impact due to the variation in rainfall during these months. It is important to consider the fact that the characteristically high rainfall in November (like the positive anomalies in the months of June, July, August and October) contributed to increasing the electricity generation capacity throughout the study period and exactly for this reason the Jurumirim presents, almost in its totality, all periods studied with at least one-year gain in generation, that did not occur in the SHEPs, where there was no year with increases in generation capacity.

The loss in electricity production capacity may not be significant when dealing with a hydroelectric plant with only $98 \mathrm{MW}$ of the Jurumirim and two SHEPs with a hypothetical $60 \mathrm{MW}$, however, if this loss was amplified to the entire river, which contains multiple HEPs with approximately $2430 \mathrm{MW}$ installed, this reduction in electricity production capacity would be significant with potential negative reflections for the regional social and economic development. The two SHEPs under study are privately owned and generate power to a large cement plant, in this case, the power generated by these two SHEPs are used to meet the electricity demands of the industry in question.

If, hypothetically, this loss was amplified for all of Brazil, with its 514.2 TWh hydroelectric power production generated in 2010 (EPE, 2011), the loss in question would be much more significant, resulting in serious energy problems potentially impossible to solve in a short-term scenario.

\section{Discussion}

Electricity consumption of a country is one of the main parameters to measure the degree of its development (Seljom et al., 2011), as it is directly connected to the degree of industrialization of the country. A possible and expressive loss in electricity production capacity could bring serious social and economic risks to the country.

The electricity distribution system in Brazil is managed by the interlinking of the Interlinked National System (SIN, in Portuguese). The advantage of this system is that it can compensate the lack of electricity production capacity in one region with the electricity generated in another, somewhat reducing the direct influence of the loss of electricity production capacity with negative impacts to regional economies. The mentioned advantage cannot be considered in the case of the North Region of the country, since it utilizes decentralized systems to 
supply the majority of the energy demand. This shortfall in Brazil's energy distribution will most likely improve in the future as studies show that about $63 \%$ of the hydroelectric potential is located in the North Region, mainly in the Amazon basin (Soito \& Freitas, 2011). The present study analyzed the headwater of a river located in the most important state of Brazil from the economic point of view: The State of São Paulo, which produces more than $30 \%$ of the Brazilian GDP, according to IBGE (2012), and serves as a serious relevant warning in this "climatic-hydro-energy-social-economic" obstacle.

The following Table 3 shows that the relationship between rainfall and water flow and between water flow and power generation.

Table 3. Generation capacity losses (in \%) and proportions among loss in the electricity generation units under study

\begin{tabular}{|c|c|c|c|c|c|c|c|}
\hline & Scenarios & $\begin{array}{l}\text { Rainfall with } \\
\text { anomalies* }\end{array}$ & Flow* & $\begin{array}{c}\text { Energy } \\
\text { generation* }\end{array}$ & $\begin{array}{c}\text { Flow/Rainfall } \\
* *\end{array}$ & $\begin{array}{l}\text { Generation } \\
\text { /Flow** }\end{array}$ & $\begin{array}{l}\text { Generation } \\
\text { /rainfall** }\end{array}$ \\
\hline \multirow{7}{*}{ 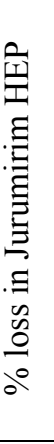 } & $1991-20$ A2 & 3.8 & 9.4 & 7.8 & 2.46 & 0.82 & 2.02 \\
\hline & $1991-20$ B2 & 4.2 & 10.1 & 8.3 & 2.43 & 0.82 & 1.98 \\
\hline & $2021-50$ A2 & 5.0 & 11.9 & 10.0 & 2.41 & 0.84 & 2.01 \\
\hline & $2021-50$ B2 & 2.9 & 7.0 & 5.6 & 2.43 & 0.80 & 1.94 \\
\hline & $2051-80$ A2 & 5.2 & 12.2 & 10.3 & 2.37 & 0.84 & 2.00 \\
\hline & $2051-80$ A2 & 2.6 & 6.4 & 5.2 & 2.48 & 0.82 & 2.03 \\
\hline & $\begin{array}{c}\text { Average } \\
\text { proportions }\end{array}$ & & & & 2.43 & 0.82 & 2.0 \\
\hline \multirow{7}{*}{ 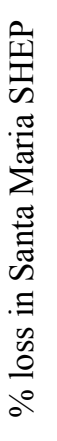 } & $1991-20$ A2 & 3.7 & 8.8 & 10.3 & 2.4 & 1.18 & 2.83 \\
\hline & $1991-20$ B2 & 4.0 & 9.5 & 10.3 & 2.38 & 1.09 & 2.61 \\
\hline & $2021-50$ A2 & 4.7 & 11.2 & 10.3 & 2.37 & 0.92 & 2.19 \\
\hline & $2021-50$ B2 & 2.7 & 6.5 & 6.9 & 2.38 & 1.06 & 2.53 \\
\hline & $2051-80$ A2 & 4.9 & 11.5 & 10.3 & 2.35 & 0.9 & 2.11 \\
\hline & $2051-80$ A2 & 2.4 & 5.9 & 6.9 & 2.42 & 1.16 & 2.82 \\
\hline & $\begin{array}{c}\text { Average } \\
\text { proportions }\end{array}$ & & & & 2.38 & 1.05 & 2.51 \\
\hline \multirow{7}{*}{ 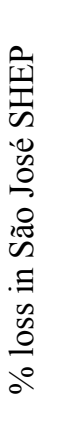 } & $1991-20$ A2 & 3.8 & 9.5 & 9.1 & 2.51 & 0.96 & 2.41 \\
\hline & $1991-20$ B2 & 4.1 & 10.2 & 9.1 & 2.50 & 0.89 & 2.22 \\
\hline & 2021-50 A2 & 4.9 & 12.1 & 13.6 & 2.48 & 1.12 & 2.79 \\
\hline & $2021-50$ B2 & 2.8 & 7.1 & 4.5 & 2.51 & 0.64 & 1.61 \\
\hline & $2051-80$ A2 & 5.1 & 12.5 & 13.6 & 2.47 & 1.09 & 2.69 \\
\hline & $2051-80$ A2 & 2.5 & 6.4 & 4.5 & 2.53 & 0.71 & 1.80 \\
\hline & $\begin{array}{c}\text { Average } \\
\text { proportions }\end{array}$ & & & & 2.50 & 0.90 & 2.25 \\
\hline
\end{tabular}

*The values were calculated by finding the percentage of loss from the average of each factor in relation to the average of the baseline (1961-90)

** Proportional value

The results show that the relationship between rainfall and water flow and between water flow and power generation are not linearly proportional because of complex phenomena of the hydrographic cycle and its electricity production, resulting in different loss percentages. It was also observed that the impact of rainfall reduction in flow production in the Alto Paranapanema Basin was accentuated. The numbers in Table 2 also 
show that the reduction in power generation closely matches reduction in water flow with positive and negative variations that depends on the characteristics and limitations of the plant turbines.

Table 3 also present, in the intersection of the "generation/rainfall" column with the "proportion means" line, that the three production units had a very unequal proportion mean for generation/rainfall, a difference that reached the $25 \%$ level. Starting from the fact that the three units are located within the same hydrographic basin (Alto Paranapanema Basin) this difference in the proportion is even more significant. In the end, if this inequality already exists in closest locations and with similar physical and climatic characteristics, this proportional difference tends to be even greater in locations that are more distant. This, in principle, discourages analyses focused on correlation between climatic variation and electricity production that do not consider the physical characteristics (hydrology, pathology and geomorphology, for example) of the exact physical locations of this energy.

Among the most important factors of this non-linearity between rainfall loss and decreased electricity generation capacity are the physical and particular factors of the plant surroundings and the individual potential of each plant that can, at times of flooding, waste energy by the outflow because of lack of generation capacity, due to the physical limitation of the plant.

\section{Conclusions}

The present study warns of the growing need to increase the electricity offer, even for reasons of energy security. It is important to emphasize that the characteristics or profiles of electricity demand and consumption are linked to the main questions of this study, as it is predicted that there is possible loss in the hydroelectric electricity production capacity, a form of energy that is considered renewable and clean. In Brazil, if these losses become more evident and real, it will be necessary to complement this electricity with another type of generation, usually made by thermal plants (as occurred in 2013), that are notorious emitters of greenhouse gases and consequently foment the climate change process, which, in turn, creates a cyclic process that can further intensify the process of loss of renewable electricity production capacity.

Considering factors such as rainfall and water flow studied in a micro basin, the present study pointed to more serious losses in the study area than predicted. The electricity production losses range from $4.5 \%$ to $10.3 \%$ and the flow loss range from $5.9 \%$ to $10.2 \%$ for scenarios $\mathrm{B} 2$ for scenario A2 the electricity losses range from $7.8 \%$ and $13.6 \%$ and the flow loss ranges from $8.8 \%$ to $12.5 \%$. The increases in electricity production in other regions will not compensate for the predicted losses in the Alto Paranapanema Basin.

Thus, in the possible context of worsening in the global climate change, medium and long-term energy planning geared to sustainability, or more pragmatically to energy efficiency, and along with satisfactory meeting of the growing energy demand, has been shown to be necessary and opportune. The results of the present study confirm that there will be impacts on hydroelectric power generation from climate change, reducing electricity production capacity in the studied area, both in SHEP and HEP generation modalities.

In this way, this work recommends that the planning of expansion of electricity sector considers the impacts of the climate change, especially in countries that, as Brazil, have an expressive hydraulic generation., incorporating scenarios regarding the climatic variations and the losses in hydroelectricity production capacity, attributed to the hydro-climatic factor.

\section{References}

Agência Nacional de Águas [ANA]. (2015). Conjuntura dos Recursos Hídricos no Brasil - Informe 2014. Encarte Especial sobre a Crise Hídrica. Brasília-DF: Superintendência de Planejamento de Recursos Hídricos.

Bazilian, M., Hobbs, B. S., Blyth, W., MacGill, I., \& Howells, M. (2011). Interactions between energy security and climate change: A focus on developing countries. Energy Policy 39, 3750-3756. https://doi.org/10.1016/j.enpol.2011.04.003

Brasil. (1997). Lei $\mathrm{n}^{\circ}$ 9.433, de 8 de janeiro de 1997. Institui a Política Nacional de Recursos Hídricos, cria o Sistema Nacional de Gerenciamento de Recursos Hídricos, regulamenta o inciso XIX do art. 21 da Constituição Federal, e altera o art. $1^{\circ}$ da Lei $\mathrm{n}^{\mathrm{o}}$ 8.001, de 13 de março de 1990, que modificou a Lei $\mathrm{n}^{\mathrm{o}}$ 7.990, de 28 de dezembro de 1989.

Brasil. (2013). Lei $\mathrm{n}^{\mathrm{o}} 12.783$, de 11 de janeiro de 2013. Dispõe sobre as concessões de geração, transmissão e distribuição de energia elétrica, sobre a redução dos encargos setoriais e sobre a modicidade tarifária; altera as Leis nos 10.438, de 26 de abril de 2002, 12.111, de 9 de dezembro de 2009, 9.648, de 27 de maio 
de 1998, 9.427, de 26 de dezembro de 1996, e 10.848, de 15 de março de 2004; revoga dispositivo da Lei no 8.631, de 4 de março de 1993; e dá outras providências.

Cicogna, M. A. (1999). Modelo de planejamento da operação energética de sistemas hidrotérmicos a usinas individualizadas orientado por objetos (Master's thesis, University of Campinas, Brazil). Retrieved from http://repositorio.unicamp.br/jspui/handle/REPOSIP/259872

Cicogna, M. A. (2003). Sistema de Suporte à Decisão para o Planejamento e a Programação de Operação de Sistema de Energia Elétrica (Doctoral thesis, University of Campinas, Campinas, Brazil). Retrieved from http://repositorio.unicamp.br/bitstream/REPOSIP/260310/1/Cicogna_MarceloAugusto_D.pdf

Cicogna, M. A., \& Soares Filho, S. (2005). HidroLab Documentação: Manuais HidroLab.

Cleto, J. (2008). Climate Change Impacts on Portuguese Energy System in 2050 (Master's thesis, Faculdade de Ciências e Tecnologia da Universidade Nova de Lisboa, Lisboa/PT). Retrieved from https://run.unl.pt/handle/10362/1794

Collischonn, W., Tucci, C. E. M., \& Clarke, R. T. (2001). Further evidence of changes in the hydrological regime of the River Paraguay: part of a wider phenomenon of climate change. Journal of Hydrology 245, 218-238. https://doi.org/10.1016/S0022-1694(01)00348-1

Empresa de Pesquisa Energética [EPE]. (2011). Balanço Energético Nacional 2011: ano base 2010. Retrieved July 27, 2017, from https://ben.epe.gov.br/downloads/Relatorio_Final_BEN_2011.pdf

Empresa de Pesquisa Energética [EPE]. (2016). Balanço Energético Nacional 2016: ano base 2015. Retrieved July 29, 2017, from https://ben.epe.gov.br/downloads/Relatorio_Final_BEN_2016.pdf

Hamada, E., Gonçalves, R. R. V., Marengo, J. A., \& Ghini, R. (2008). Cenários climáticos futuros para o Brasil. In R. Ghini, \& E. Hamada (Eds.), Mudanças Climáticas: Impactos sobre doenças de plantas no Brasil (pp 25-74). Brasília-DF: Empraba.

Instituto Brasileiro de Geografia e Estatística [IBGE]. (2012). Produto Interno Bruto dos Municípios. Retrieved January 4, 2017, from http://www.ibge.gov.br

Integrated Water Resources Management System (in portuguese: Sistema Integrado de Gerenciamento dos Recursos Hídricos [SIRGH]. (2017). Retrieved July 31, 2017, from http://www.sigrh.sp.gov.br/apresentacao

Intergovernmental Panel on Climate Change [IPCC]. (2007). Climate Change 2007: The Physical Science Basis. Contribution of Working Group I to the Fourth Assessment Report of the Intergovernmental Panel on Climate Change. Retrieved July 22, 2017, from https://www.ipcc.ch/pdf/assessment-report/ar4/wg1/ar4-wg1-frontmatter.pdf

Intergovernmental Panel on Climate Change [IPCC]. (2014). Climate Change 2014: Synthesis Report Contribution of Working Groups I, II and III to the Fifth Assessment Report of the Intergovernmental Panel on Climate Change. Retrieved November 27, 2016, from https://www.ipcc.ch/pdf/assessment-report/ar5/syr/SYR_AR5_FINAL_full_wcover.pdf

Lopes, J. E. G. (1999). Manual do modelo Soil Moisture Accounting Procedure (SMAP). Retrieved January 5 , 2016, from http://pha.poli.usp.br/LeArq.aspx?id_arq=3596

Lopes, J. E. G., Braga, B. P. F., \& Conejo, J. G. L. (1982). SMAP, a simplified Hydrological Model, Applied modeling in Catchment Hidrology, Ed V.P. Singh, Water Resources Publications.

Lucena, A. F. P., Szklo, A. S., Schaeffer, R., \& Dutra, R. M. (2010). The vulnerability of wind power to climate change in Brazil. Renewable Energy, 35, 904-912. https://doi.org/10.1016/j.renene.2009.10.022

Lucena, A. F. P., Szklo, A. S., Schaeffer, R., Souza, R. R., Borba, B. S. M. C., da Costa, I. V. L., ... da Cunha, S. H. F. (2009). The vulnerability of renewable energy to climate change in Brazil. Energy Policy, 37, 879-889. https://doi.org/10.1016/j.enpol.2008.10.029

Muñoz, J. R., \& Sailor, D. J. (1998). A modelling methodology for assessing the impact of climate variability and climatic change on hydroelectric generation. Energy Conversion and Management, 39, 1459-1469. https://doi.org/10.1016/S0196-8904(98)00017-X

Sanderson, M. (1987). Implications of climate change for navigation and power generation in the great lakes. Climate Changes Digest (pp. 97-03). Windsor-ON: Great Lakes Institute, University of Windsor Report.

Schaeffer, R., Lucena, A. F. P., \& Szklo, A. S. (2008). Climate Change and Energy Security - Tecnical Report. Rio de Janeiro - RJ: PPE/COPPE/UFRJ. 
Schaeffer, R., Szklo, A. S., Lucena, A. F. P., Borba, B. S. M. C., Nogueira, L. P. P., Fleming, F. P., ... Boulahya, M. S. (2012). Energy sector vulnerability to climate change: A review. Energy, 38, 1-12. https://doi.org/10.1016/j.energy.2011.11.056

Seljom, P., Rosenberg, E., Fidje, A., Haugen, J. E., Meir, M., Rekstad, J., \& Jarlset, T. (2011). Modelling the effects of climate change on the energy system-A case study of Norway. Energy Policy, 39, 7310-7321. https://doi.org/10.1016/j.enpol.2011.08.054

Soito, J. L. S., \& Freitas, M. A. V. (2011). Amazon and the expansion of hydropower in Brazil: Vulnerability, impacts and possibilities for adaptation to global climate change. Renewable and Sustainable Energy Reviews, 15, 3165-3177. https://doi.org/10.1016/j.rser.2011.04.006

Tucci, C. E. M. (2002). Impactos da variabilidade climática e do uso do solo nos recursos hídricos. Retrieved May 5, 2016, from http://www.cepal.org/samtac/noticias/documentosdetrabajo/6/23336/InBr02902.pdf

Tucci, C. E. M., \& Clarke, R. T. (1998). Environmental issues in the La Plata Basin. Water Resources Development, 14(2), 157-173. https://doi.org/10.1080/07900629849376

\section{Notes}

Note 1. IPCC scenarios, widely used for climate change modelling. The A2 scenario family describes a typically heterogeneous world. The main focus is self-reliance and preservation of local identities. Fertility patterns across regions converge typically slowly, which results in continuously increasing population. Economic development is primarily regionally oriented and per capita economic growth and technological change more fragmented and slower than other scenarios. The B2 scenario, focused on regional and local levels, family describes a world in which the emphasis is on local solutions to economic, social and environmental sustainability and related with intermediate levels of economic development, and not so fast but very diverse technological change.

\section{Copyrights}

Copyright for this article is retained by the author(s), with first publication rights granted to the journal.

This is an open-access article distributed under the terms and conditions of the Creative Commons Attribution license (http://creativecommons.org/licenses/by/4.0/). 